\title{
SIKAP PEGAWAI RRI BENGKULU TENTANG TAYANGAN TALKSHOW MARIO TEGUH GOLDEN WAYS DI METRO TV SEBAGAI MOTIVASI KERJA
}

Oleh:

\author{
JUSARMAN SANUSI, YUSUARSONO, SRI NARTI \\ Prodi Ilmu Komunikasi FIS Universitas Dehasen Bengkulu
}

\begin{abstract}
The purpose of this study was to determine the attitude of Indonesia Republic Radio employees Bengkulu after watching Mario Gonden Waystalkshow on Metro TV as motivation to work.Data analysis technique used is descriptive qualitative method.Data were collectedby using observation, interviews and documentationtechniques. This study uses five informants, they weretwo staffs, one announcer and two journalists of Indonesia Republic RadioBengkulu.This study presented data based on interviews, observation and documentation in the form of words.Analyses were performed by using the $S-O-R$ theorythat is Stimulus, Organism and Response.Based on this research, it found that employees of RRI Bengkulu likedthe impressions of the talkshow for it's considered capable of providing good information and motivation to work.Meanwhile, if it seen from the attitude changes, therewere changes in employee attitudes after watching Mario Teguh Golden Ways on Metro $T V$. Changes in attitude toward a better than ever, especially in terms of work, the employee of Radio Republic Indonesia Bengkulu feel motivated to work harder to reach the ideals to be expected during this time. This event was considered to have helped to generate employment for employee motivationin Radio Republic Indonesia Bengkulu.
\end{abstract}

Keywords: Attitude, Impressions, Talkshow, Motivation

\section{PENDAHULUAN}

Saat ini kita hidup dalam masyarakat komunikasi massa, yaitu suatu masyarakat yang kehidupan kesehariannya tidak bisa dilepaskan dari media massa. Masyarakat komunikasi massa menjual dan membeli barang, mencari informasi muktahir, mencari bahan untuk pendidikan, mencari hiburan dan mencari pencerahan serta peneguhan dirinya melalui media massa (Karlinah dkk, 2010: 01). Selain itu manusia adalah makhluk sosial yang tidak dapat melepaskan diri dari jalinan reaksi sosial, dimana manusia akan selalu mengadakan kontak sosial yang selalu berhubungan dengan orang lain. Menurut $\mathrm{Dr}$ Everett Kleinjan, komunikasi sudah merupakan bagian kekal dari kehidupan manusia seperti halnya bernafas, jadi sepanjang manusia ingin hidup maka ia perlu berkomunikasi (Cangara, 2005: 56). Komunikasi bukan hanya melalui tatap muka saja tetapi juga dengan menggunakan media massa baik cetak maupun elektronik, seperti surat kabar, majalah, radio dan televisi.

Televisi merupakan salah satu media massa yang paling umum digunakan. Sehingga televisi lah yang paling berpengaruh dalam kehidupan manusia. Melalui program acara seperti talkshow, berita, kuis, dan musik, yang dapat memenuhi kebutuhan dan keinginan khalayak dalam mendapatkan hiburan dan informasi yang mereka butuhkan seperti acara takshow Mario Teguh Golden Ways di metro TV. Acara Mario Teguh Golden Ways pernah mendapatkan Choice Award 
sebagai program TV terbaik di Indonesia pada tahun 2015 dan bahkan mendapat kan penilaian yang baik dari Komisi Penyiaran Indonesia (KPI), untuk beberapa tahun ini, karena dinilai tidak hanya mampu untuk memotivasi, tetapi sosok Mario Teguh juga menjadi sumber inspirasi bagi kita dalam membentuk sikap yang baik. Sedangkan audiens yang menonton pun terdiri dari berbagai latar belakang yang berbeda-beda baik usia, pendidikan, maupun pekerjaan. Motivasi sebagai upaya yang dapat memberikan dorongan kepada seseorang untuk berbuat, karena perilaku seseorang yang cenderung mengarah pada tujuan dan dorongan oleh keinginan untuk mencapai tujuan tertentu, karena motivasi akan menyebabkan terjadinya perubahan pada diri manusia yang akhirnya mendorong kita untuk melakukan sesuatu (Rakhmat, 2007: 12).

Program ini sangat menarik perhatian audiensnya,karena dinilai mampu untuk mempengaruhi sikap dan cara pandang seseorang. Baik itu di rumah, di sekolah ataupun di tempat bekerja. Seperti halnya yang terjadi pada pegawai RRI Bengkulu yang berdasarkan observasi awal penulis, dari 120 orang pegawai yang bekerja di sana, sebagian diantaranya menyatakan suka menonton acara Mario Teguh Golden Ways tersebut, karena pesan-pesan yang disampaikan sangat menarik, dan motivasi sangat di butuhkan untuk memulihkan kembali semangat yang sempat hilang karena tekanan pekerjaan dan bahkan tekanan yang datang dari lingkungan keluarga sehingga akan berdampak terhadap hasil kinerja seseorang. Dan keberhasilan adalah hal yang menjadi prioritas utama dalam bekerja, karena tanpa keberhasilan maka pekerjaan seseorang dianggap gagal seperti yang dituangkan dalam isi pesan tayangan talkshow pada episode yang penulis pilih. Di mana keberhasilan itu ditentukan oleh diri sendiri, jika ia sunggug-sungguh dalam bekerja maka ia akan menemukan titik

keberhasilan.https://www.youtube.com/wat ch? $v=F 2 g X 2 p S B x V Y \&$ list $=$ PLtM3dqXh9G yaX6U9ke4xwgit0qPc8rrEN

Kesibukan sebagai pegawai media penyiaran milik publik pasti membuat mereka mengalami kejenuhan tekanan dan lain sebagainya yang bisa menurunkan semangat pegawai dalam bekerja. Sehingga membuat pekerjaan menjadi terganggu karena pengaruh dari menurunya kinerja pegawai tersebut. Untuk itulah dirasa perlu untuk mendapatkan motivasi kerja kembali. Agar hasil kerja yang didapatkan maksimal banyak cara yang dapat dilakukan salah satunya dengan menonton tayangan Mario Teguh Golden Ways ini.

Berdasarkan latar belakang di atas, maka penulis merasa tertarik untuk mengangkat judul penelitian penulis yaitu: Sikap Pegawai RRI Bengkulu Tentang Tayangan Talkshow Mario Teguh Golden Ways di Metro TV Sebagai Motivasi Kerja. (Pada Episode "Keberhasilan, Demikian Dekat Dilidah; Tetapi Bisa Demikian Jauh Dari Jangkauan”).

\section{METODE PENELITIAN}

Jenis penelitian yang penulis gunakan adalah metode deskriptif kualitatif. Menurut Bogdan dan Taylor seperti dikutip Moleong (2002:3), metode penelitian kualitatif sebagai prosedur penelitian yang menghasilkan data deskriptif berupa kata-kata tertulis atau lisan dari orang dan perilaku yang diamati. Penelitian kualitatif dapat diartikan sebagai penelitian yang bermaksud untuk memahami fenomena tentang apa yang dialami oleh subjek penelitian, misalnya perilaku, persepsi, motivasi, tindakan, dan yang lainnya secara holistic dan dengan cara deskripsi dalam bentuk kata-kata dan bahasa pada suatu konteks khusus yang alamiah dan dengan memanfaatkan berbagai metode alamiah (Moleong,2013:6).Sedangkan metode deskriptif menurut Ruslan (2003:86) bertujuan untuk menggambarkan tentang sikap dan karakteristik sekelompok orang 
atau ciri-ciri individu,situasi tertentu. Penelitian relatif sederhana dan tidak memerlukan landasan teoritis rumit atau pengajuan hipotesis tertentu.

Lokasi penelitian dilakukan di kantor Radio Republik Indonesia RRI Kota Bengkulu, dan waktu penelitian dimulai pada tanggal 4 April sampai dengan 4 Mei 2016.

Objek penelitian ini adalah tayangan acara talkshow Mario teguh golden ways pada episode, "Keberhasilan Demikian Dekat di Lidah, Tetapi Bisa Demikian Jauh Dari Jangkauan'.Subjek penelitian yaitu Pegawai Radio Republik Indonesia RRI Bengkulu yang menonton tayangan Mario teguh golden ways episode, "Keberhasilan Demikian Dekat di Lidah, Tetapi Bisa Demikian Jauh Dari Jangkauan". Adapun informan yang penulis gunakan dalam penelitian ini adalah sebanyak 5 orang pegawai RRI Bengkulu yang menyukai tayangan Mario teguh golden ways dan khususnya menonton pada episode, "Keberhasilan Demikian Dekat di Lidah, Tetapi Bisa Demikian Jauh Dari Jangkauan”.

Tabel 1Informan Penelitian

\begin{tabular}{|c|c|c|}
\hline No & Nama\& Jabatan & $\begin{array}{c}\text { Jenis } \\
\text { Kelamin }\end{array}$ \\
\hline 1 & $\begin{array}{c}\text { Marli } \\
\text { Efendi/Penyiar }\end{array}$ & Laki-laki \\
\hline 2 & Nurul/Wartawan & Perempuan \\
\hline 3 & $\begin{array}{c}\text { Elly Daniarti/ } \\
\text { Kasi komunikasi } \\
\text { publik RRI }\end{array}$ & Perempuan \\
\hline 4 & Shovy/Wartawan & Perempuan \\
\hline 5 & Riska/Wartawan & Perempuan \\
\hline
\end{tabular}

Sumber: Data diperoleh Penulis,2016

Dari tabel di atas dapat dilihat jumlah informan penelitian ini berjumlah lima orang dan terdiri dari satu orang lakilaki dan empat orang perempuan, dari kelima informan ini memiliki latar belakang pekerjaan yang berbeda, yang terdiri dari 2 oarang wartawan, satu orang penyiar, satu orang staf acara dan satu orang kasi, dan kesemua informan ini memiliki pendidikan sarjana, penulis menyakini jika kelima informan ini memiliki pengetahuan yang dinilai layak dalam memberikan informasi kepada penulis, karena mereka adalah orang-orang pilihan penulis, yang benar-benar mengetahui dan menonton tayangan talkshow Mario Teguh Golden Ways di Metri TV. Teknik pengumpulan data yang akan digunakan dalam penelitian adalah observasi, wawancara, dan dokumentasi. Observasi adalah yaitu metode pengumpulan data yang dilakukan dengan cara mengamati dan mencatat secara rinci gejala-gejala yang sedang diselidiki. Wawancara adalah percakapan dengan maksud tertentu. Percakapan itu dilakukan oleh dua pihak, yaitu pewawancara yaitu pihak yang mengajukan pertayaan dan terwawancara yaitu pihak yang memberikan jawaban atas pertanyaan tersebut (Moleong, 2013:186). Dalam penelitian ini, penulis menggunakan wawancara terstruktur pada pegawai RRI Bengkulu. Wawancara terstruktur adalah wawancara yang menggunakan data wawancara yang telah dibuat sebelum melakukan wawancara.Sedangkan dokumentasi adalah pengumpulan data dengan menggunakan dan mempelajari dokumentasi atau arsip-arsip atau catatan, foto, tabel, maupun peta tempat dijadikan penelitian, dimana dengan dokumentasi yang ada dapat memberikan gambaran tentang keadaan daerah penelitian (Koentjoroningrat, 1999:228). Dokumentasi yang penulis gunakan dalam penelitian ini seperti jurnal,foto dan lainnya.

Jenis data yang digunakan dalam penelitian ini adalah data primer dan data sekunder.Data primermerupakan sumber data yang di peroleh secara langsung dari sumber asli atau pihak pertama, data primer di kumpulkan oleh penelitiuntuk menjawab pertanyaan riset atau penelitian. Data primer sendiri dapat berupa pendapat subjek baik secara individu maupun secara kelompok, hasil observasi suatu benda 
(fisik), kejadian, atau kegiatan dan hasil pengujian (Mulyana,2003:60).Data Sekundermerupakan data yang sudah ada sebelumnya atau yang telah disediakan oleh instansi atau lembaga yang terkait seperti brosur, leaflet, koran, serta bukubuku dan perangkat fisik lainya yang berhubungan dengan penelitian ini pelatihan jurnalistik televisi (PJTV).Setelah memperoleh data dari hasil wawancara, langkah selanjutnya adalah data-data tersebut disusun dan dianalisis dengan metode analisis data. Analisis data adalah proses mencari dan menyusun datasecara sistematis data yang diperoleh dari hasil wawancara dan angket, catatan lapangan, dan bahan-bahan lain, sehingga dapat mudah dipaham, dan temuannya dapat diinformasikan kepada orang lain (Sugiyono, 2009:244).

Langkah-langkah dalam pengumpulan datahingga pengambilan keputusan adalah sebagai berikut(Moleong,1990:76):

a. Mengumpulkan informasi atau data yang berkaitan dengan masalah yang diteliti di lapangan baik primer maupun sekunder.

b. Memberikan data yang diperoleh dari lapangan. Mengadakan pemeriksaan data yang diperoleh dilapangan disesuaikan dengan tujuan penelitian, sehingga dapat diperoleh hasil akhir yang akurat dari data tersebut.

c. Menyusun klarifikasi informasi dari data yang diperoleh. Input ini diproses melalui beberapa tahapan yaitu, pengumpulan informasi, pemrosesan data. Setiap tahapan tersebut dapat mempengaruhi akurasi dan kualitas kesimpulan yang akan di dapat.

d. Mendeskripsikan sekaligus menganalisis dan menginterpretasikan data. Di dalam menganalisis data yang didapat tergantung dari jenis informasi dan kategori laporan penelitian. Jenis informasinya bisa berupa deskriptif, mengambil kesimpulan merupakan tahapan yang paling akhir, yaitu memberi informasi tentang apa yang telah dilakukan oleh peneliti secara singkat dan padat dari keseluruhan data laporan yang diperolah dari penelitian.

\section{HASIL PENELITIAN DAN \\ PEMBAHASAN \\ Hasil Penelitian}

Pada penelitian ini, penulis ingin melihat sikap pegawai RRI Bengkulu tentang tayangan talkshow Mario teguh golden ways pada episode," Keberhasilan Demikian Dekat di Lidah, Tetapi Bisa Demikian Jauh Dari Jangkauan", melalui tayangan ini dapat dilihat respon pegawai RRI Bengkulu setelah menonton acara tersebut. Respon ini dapat dilihat dengan cara mengkaji teori S-O-R seperti menurut Effendy dalam teorinya. Penulis melakukan wawancara terhadap lima orang informan dan penulis juga melakukan observasi di kantor Radio Republik Indonesia RRI Bengkulu. Berikut hasil wawancara dan observasi yang penulis dapatkan dilapangan:

\section{Stimulus}

Stimulus adalah rangsangan atau dorongan, sehingga unsur stimulus dalam teori ini merupakan perangsang berupapesan (message) atau hasil pernyataan. Pesan yang disampaikan melalui tayangan Mario Teguh golden ways di metro TV menurut pegawai RRI Bengkulu, berikut saudari Nurul dalam hasil wawancaranya mengatakan:

"Ambo meraso cocok dengan tayangan acara MTGW pada episode 'Keberhasilan demikian dekat di lidah, tetapi bisa demikian jauh dari jangkauan' ini, kareno setelah ambo nonton acara iko ambo raso sesuai dengan pengalaman pribadi ambo sebagai wartawan perempuan di RRI iko,kareno sebelumnyo ambo merasa dak percayo diri kerjo sebagai wartawan yang mayoritasnyo lakilaki".(Wawancara, Hari jumat 8 April 2016) 
Dari hasil wawancara saudari Nurul di atas, tayangan ini dapat memberikan semangat kepadanya, walaupun dia wartawan perempuan, namun tidak menyurutkan semngatnnya untuk mendapatkan posisi atau jabatan yang setara dengan kaum laki-laki. Yang tadinya dia hanya beranggapan bahwa sangat susah untuk melakukan pekerjaan yang rata-rata dilakukan oleh kaum lakilaki. Namun melalui tayangan MTGW episode ini pesan yang disampaikan dapat memberikan masukan yang positif agar bisa bekerja dan bersaingan meskipun kompetitor di kantor mayoritas adalah kaum laki-laki. Asalkan kita yakin dan mau bekerja sungguh-sungguh, pasti membuahkan hasil yang baik. Hal ini didukung dengan hasil observasi yang berhasil penulis himpun saat melakukan penelitian pada pegawai RRI Bengkul. Dalam hal ini, tayangan Mario teguh golden ways di metro TV dinilai sangat bermanfaat dan mampu memberikan dorongan melalui pesan-pesan singkat penuh makna dari sang motivator yaitu bapak Mario teguh selaku pembawa acara dalam tayangan talkshow ini.

Sementara itu, hasil wawancara penulis dengan saudara Marli Efendy, dia mengatakan bahwa tayangan Mario teguh golden ways episode," Keberhasilan Demikian Dekat di Lidah, Tetapi Bisa Demikian Jauh Dari Jangkauan”, yaitu sebagai berikut:

"Ya, secara pribadi, abang tertarik
dengan tayangan episode kali ini,
karena tayangannya abang raso
cukup untuk memberikan
pencerahan dan penyemangat
abang kalo lagi galau oleh
pekerjaan, dan yang lainnya selain
memberi penyemangat tayangan
mario teguh iko banyak
mengandung pesan-pesan
moral".(wawancara Hari sabtu 9
April 2016)

Sedangkan hasil dari observasi yang penulis peroleh di kantor RRI Bengkulu yaitu tayangan Mario teguh ini, selain memberikan pesan yang bermanfaat, dinilai cukup mendidik dan yang menarik dari tayangan Mario teguh ini karena selalu menyajikan tema-tema yang sangat menyentuh hati bagi yang menontonnya. Ada semacam penyemangat baru yang muncul dalam diri kita ketika menyaksikan episode ini. Selain itu pesan-pesan yang disampaikan oleh sang motivator Mario teguh ini cukup baik, pesan yang disampaikan cukup sederhana dan singkat, namun dari kesingkatan pesan yang disampaikan memiliki arti dan makna yang luas, dan banyak sekali pesan yang disampaikan oleh Mario teguh ini menjadi penyemangat. Seperti halnya hasil wawancara yang diungkapkan oleh ibu Elly sebagai berikut:

"Ya kalo menurut aku pesan yang ada dalam tayangan Mario teguh episode ini cukup baiklah, karena menurut aku segalo pesan yang disampaikannyo setiap episodenya memiliki nilai yang baik galo, terkhusu pada episode iko memang memiliki arti yang cukup menarik perhatian dan memiliki makna yang tinggi untuk di cermati".(Hasil wawancara hari jumat 8 April 2016)

Sedangkan hasil observasi yang diperoleh dari penelitian ini tentang tentang tayangan Mario teguh golden ways episode ini, stimulus yang berupa pesan yang disampaikan kepada penontonnya yakni pegawai RRI Bengkulu dinilai cukup baik dan variatif. Hampir semua pesan yang disampaikan oleh sang motivator Mario teguh cukup baik dan memiliki nilai yang positif, dan memberikan gambaran serta pencerahan pemikiran yang positif tentang hal-hal yang akan kita lakukan untuk mencapai sesuatu yang telah kita rencanakan atau yang telah kita targetkan. Episode ini menceritakan tentang suatu hal yang tidak akan tercapai apabila kita tidak memiliki keseriusan yang cukup maka apapun yang kita rencanakan tidak akan tercapai, begitupun sebaliknya jika kita berada pada 
posisi yang paling bawah tetapi jika kita memiliki komitmen dan niat yang baik maka kita akan mendapatkan kesuksesan yang diinginkan, hal ini juga di ungkapkan serupa oleh ibu Riska dalam wawancaranya sebagai berikut:

"Kalo menurut sayo episode ini benar, karena kesuksesan atau keberhasilan itu kalo dak serius kito dak akan dapat mencapainyo walaupun lah bakalan kito pegang, harus usaha keras dan niat yang bulat, aku setuju dengan episode ini"..(Hasil wawancara hari senin 11 April 2016)

Berdasarkan hasil wawancara di atas sama halnya dengan hasil observasi yang telah berhasil penulis himpun, bahwa hampir semua pesan yang disampaikan pada episode ini memang benar keberhasilan itu tidak mudah untuk digapai karena membutuhkan waktu, niat dan pengorbanan cukup tinggi untuk menggapainya, terkadang kita jika sudah kecewa atau jatuh kita sudah patah semangat padahal dengan kegagalan itu kita bisa berusaha belajar apa yang harus kita pelajarai agar menjadi lebih baik lagi dan bisa menggapai cita-cita yang kita inginkan. Selanjutnya pesan yang disampaikan oleh Mario teguh dalam setiap episodenya pun sangat memberikan motivasi bagi audiennya, karena di setiap pesan yang ia sampaikan pasti memiliki nilai dan arti jika kita memahaminya dengan teliti. Selain itu pesan pada episode ini mampu memberikan jawaban serta solusi terhadap audienya yang bertanya dan meminta pendapat terhadap permasalahan yang sedang mereka rasakan saat itu. Seperti hasil wawancara yang di sampaikan saudari shovy berikut ini:

"Yoo, kalo menurut sayo pesan yang di sampaikan oleh mario teguh ini cukup baik, aku lagi butuh motivasi dan penyemangat untuk bekerja karena akhir-akhir ini aku lagi down dan malas nian rasonyo endak kerjo”.(Hasil wawancara hari senin 11 April 2016)

Sedangkan hasil observasi menyebutkan bahwa pesan yang disampaikan dapat memberikan semangat apalagi pada saat memang lagi membutuhkan penyemangat dan motivasi yang bersifat membangun, semangat untuk tetap melakukan sesuatu terhadap kemajuan karir dalam bekerja dan berbuat untuk menjadi lebih baik lagi. Hal ini menunjukkan bahwa pesan yang disampaikan oleh Mario Teguh ini bisa menjadi salah satu sumber pesan dan penyemangat yang baik bagi semuanya untuk menjadi lebih baik lagi.

\section{Organism}

Organism adalah badan yang hidup, sudah berarti manusia atau dalam istilah komunikan, sehingga unsur organism dalam teori ini adalah receiver (penerima pesan). Sebagai penerima pesan dalam hal ini adalah Pegawai RRI Bengkulu yang menonton tayangan Mario teguh golden ways di metro TV, menurut hasil wawancara penulis dengan saudara Marli Efendy berikut ini:

"Ya kalo menurut abang, sosok Mario teguh ini adalah sosok yang baik, cerdas, pintar dalam hal memberikan motivasi dan menghibur para audiennya yang membutuhkan motivasi atau penyemangat".(Wawancara hari sabtu 9 April 2016)

Hal senada juga juga disampaikan oleh ibu Riska yaitu:

"Kalo menurut ibu pak Mario teguh ini memiliki keterampilan mengelolah pesan itu cukup baik baik dan benar, selain itu dio jugo pintar dalam memberikan motivasi" (Wawancara hari senin 11 April 2016)

Berdasarkan hasil observasi penulis menunjukan bahwa mereka menyukai sosok sang motivator dari acara Mario teguh golden ways ini, selain memiliki karakter mudah tersenyum ia juga 
memiliki kecerdasan yang tinggi dalam memberikan motivasi bagi audiennya yang lagi butuh pesan yang isinya bersifat mendidik dan membangun. Sosok Mario teguh menjadi panutan bagi mereka dalam meniti karir di tempat mereka bekerja.

$$
\text { Selanjutnya pada episode }
$$

keberhasilan demikian dekat di lidah, tetapi bisa demikian jauh dari jangkauan ini cukup baik dan menggambarkan jika keberhasilan itu mudah digapai tetapi bisa juga susah digapai seperti yang di ungkapkan oleh saudari Nurul berikut ini:

"Yo, kalo menurut aku tayangan ini khusus episode iko, emang benar keberhasilan itu mudah asalkan kito benar-benar untuk menggapainyo, tetapi kalo kito asal jadi ajo dak kan tercapai kesuksesan itu, kareno kito yang kerjo sungguh-sungguh ajo belum tentu berhasil apolagi kito asalasalan".(Wawancara hari jumat 8 April 2016)

Sedangkan hasil observasi penulis pada pegawai di kantor RRI Bengkulu bahwa episode kali ini benar-benar membuat mereka untuk berfikir lebih mendalam untuk menggapai kesuksesan itu kuncinya kita harus serius dan memiliki niat bulat dan disertai kerja keras maka kita akan menggapai yang namanya kesuksesan itu. Menurut mereka, pesan yang disampaikan membuat mereka termotivasi untuk bekerja lebih giat lagi. Sosok Mario Teguh menjadi sumber inspirasi bagi mereka sat ini. Sebagai penerima pesan dalam tayangan Mario teguh golden ways ini, diharapkan dapat memberikan pandangan yang positif dalam dirinya untuk mengaplikasikan apa yang sudah disarankan oleh bapak Mario teguh dalam episode ini. Berikut hasil kutipan wawncara penulis dengan ibu Elly:

"Ya kalo menurut ibu pengaruh yang ibu rasakan dalam bekerja, biasanya kalo ibu sudah capek dan tak semangat kerjo, ibu seringi nonton acara mario teguh ini, apo lagi kinikan bisa lewat internet kapan saja kapan biso dilihat untuk mencari motivasi yang sifatnya memberi semangat".(Hasil wawancara hari jumat 8 April 2016)

Sedangkan hasil observasi menyatakan bahwa tanggapan mereka sangat berpengaruh terhadap perilaku seseorang setelah kita menyaksikan tayangan episode kali ini. Dari judulnya saja sudah membangkitkan motivasi bagi kita. Episode sangat besar pengaruhnya terhadap pekerjaan, karena berhubungan dengan kesuksesan seseorang dalam bekerja. Setelah mendengar masukan dengan saran dari bapak Mario teguh dalam tayangan ini, sikap berubah menjadi lebih baik dan suasana hati yang menyenangkan ketika melaksanakan pekerjaan. Hal senada juga di sampaikan oleh saudari shovy dalam wawancaranya di bawah ini:

"Ya kalo perubahan sikap yang aku rasokan ado lah seperti kalo sayo lagi liputan sayo lebih semangat dan optimis, apo lagi mau wawancara pejabat, sayo harus bersifat sopan dan selalu seyum agar tidak mengecewakan mereka meskipun sayo cape".(Hasil wawancara hari senin 11 April 2016)

Sedangkan hasil observasi yang berhasil penulis himpun, yaitu sebenarnya, hampir sama dengan wawancara di atas, karena ini pesan yang mereka terima melalui tayangan episode ini sangatlah berisi tentang motivasi kerja yang bersifat membangun berserta dengan solusi yang masuk akal sekali apabila kita cermati dengan seksama. Kata demi kata berisikan motivasi agar bekerja maksimal untuk mendapatkan hasil yang maksimal juga, selain itu juga, sosok Mario teguh dapat memberikan sumber motivasi bagi mereka sehingga mereka mersa cocok dan sangat mendambakan bapak Mario teguh ini. 


\section{Respon}

Dan yang terakhir adalah respon yang berupa reaksi, tanggapan, jawab, pengaruh, efek atau akibat, jadi dalam teori ini unsur respon adalah efek (pengaruh). Adapun tanggapan informan dalam penelitian ini, dapat dilihat dari hasil wawancara penulis terhadap ibu Elly berikut ini:

"Selaku Kasi komonikasi publik di lembaga milik pemerintah jadi saya harus pandai memilah atau memilih kata-kata yang mana yang layak saya sampaikan, jika tidak secara tidak saya langsung menjatuhkan martabat dari instansi saya bekerja, selain itu cara berpakaian juga harus saya perhatikan dan harus pandai menempatkan diri di mana saya berada agar keberhasilan senantiasa menghampiri kita seperti yang disampaikan oleh bapak Mario Teguh".(Wawancara hari jumat 8 April 2016)

Berdasarkan hasil observasi selanjutnya respon yang terjadi pada audiennya setelah menyaksikan acara Mario Teguh ini pasti ada, baik itu perubahan emosional maupaun perubahan gaya berbicara, berpakaian dan yang lainnya, hal ini menunjukan bahwa acara mario teguh bisa dikatakan berhasil mempengaruhi sifat audiennya dalam memberikan motivasi seperti yang diungkapkan oleh saudari Riska berikut ini:

"Menurut saya episode ini mampu mempengaruhi sikap saya untuk bekerja lebih serius lagi dan sungguh memotivasi saya agar optimis dalam bekerja dan berkarir di kantor, karena pesan yang di sampaikan dalam episode ini cukup baik selain banyak memberi perbandingan, dalam episode ini juga mampu memberikan pandangan yang baik untuk kedepannya".(Wawancara hari senin 11 April 2016)
Sedangkan hasil observasi menyatakan bahwa perubahan sikap itu terjadi apabila sebuah tayangan yang disajikan itu dinilai bermanfaat dan bisa membuat orang merasakan perubahan itu berdampak baik bagi mereka. Selanjutnya pengaruh dari sebuah tayangan acara itu bisa dirasakan jika audiensnya mengalami menyukai hal atau tema dibicarakan, pengaruh ini bisa berupa semangat dan motivasi kerja meskipun sedang capek, serta cara kerja mereka yang mungkin dahulunya hanya bekerja sekedarnya namun setelah menonton tayangan ini, efek yang dapat di rasakan selalu bersemangat dalam bekerja. Selain itu juga saya menyukai sosok bapak Mario teguh teguh ini, saya kagum dengan beliau mulai dari cara beliau berpakaian, gaya bahasa, serta tutur kata beliau, yang terkadang tanpa disengaja saya adopsi cara beliau berbicara dihadapan orang banyak. Bahkan ada beberapa kata beliau yang saya kutip ketika wawancarai seseorang, beliau sumber inspirasi bagi saya. Seperti diungkapkan juga oleh saudari Nurul dalam wawancaranya berikut ini:

"Ya kalo pengaruh yang aku rasokan dari segi berfikir, dahulu sayo cuma beranggapan aku kerjo untuk cari duit bae,tetapi setelah aku pikir-pikir kalo aku serius bekerjo capo tau aku biso memiliki jabatan yang lebih baik lagi di tempat aku kerjo". (Wawancara, Jumat 8 April 2016)

Hal serupa juga disampaikan oleh saudara Marli berikut ini:

"Secara pribadi saya banyak merasakan perubahan yang begitu baik bagi saya, apalagi isi pesan dari episode ini, karena dahulunya saya menjadi seorang penyiar itu selalu takut dengan salah, dan jika saya salah rasanya saya takut untuk mencobanya lagi, padahal dengan salah kita bisa menjadi lebih baik lagi".(Wawancar jumat 8 April 2016) 
Dari hasil wawancara di atas menunjukan adanya perubahan sikap yang mereka rasakan pada diri mereka seperti tingkat percaya diri mereka menjadi lebih tinggi perubahan itu juga membuat mereka merasa lebih nyaman dengan apa yang mereka lakukan dan kegagalan bukan menjadi penghalang untuk menuju kesuksesan. Tapi dijadikan sebagai bahan pelajaran untuk mencapai kesuksesan.

Sedangkan sikap pegawai RRI Bengkulu jika dilihat dari komponen afektif, menunjukan bahwa isi pesan pada tema ini sangat disukai dan digemari oleh mereka. Dalam artian, isi pesan ikut mempengaruhi perasaan mereka ketika menonton acara tersebut. Sehingga isi pesan yang disampaikan dapat merubah suasana hati seseorang yang sebelumnya merasa bosan dengan kesibukan, tekanan pekerjaan dan memiliki sifat murah menyerah terhadap pekerjaan yang belum memberikan keberhasilan. Tidak jarang dari sekian banyak pegawai yang betah dan bertahan terhadap pekerjaan yang sedang digelutinya.

Isi pesan dari acara MTGW ini ikut berperan dalam menetralisir perasaan emosional pegawai. Banyak hal yang sudah terjadi ketika bekerja, mungkin berupa teguran dari atasan, kondisi lingkungan di tempat bekerja yang kurang baik atau masalah-masalah lain dengan sesama rekan kerja. Karena jika ini dibiarkan berlarut-larut akan mempengaruhi iklim komunikasi dalam organisasi menjadi tidak kondusif. Hal ini menjadikan kita menjauh dari kesempatan untuk mendapatkan posisi yang lebih baik lagi di tempat kita bekerja. Seperti di ungkapkan oleh saudara Marli Efendi selaku penyiar RRI Bengkulu di bawah ini:

"Secara pribadi saya merasa senang dengan tayangan dari Mario Teguh ini, karena apa yang disampaikannya pada episode ini apa yang saya rasakan saat ini sehingga memberikan motivasi tersendiri bagi saya untuk bekerja lebih baik lagi”.'(Wawancara hari jumat 8 April 2016)

Hal ini menunjukan bahwa perubahan sikap seseorang itu ada pada saat ia melihat atau setelah menyaksikan tentang sesuatu kejadian atau sebuah acara yang ditayangkan oleh sebuah media seperti televisi. Perubahan sikap yang dialami oleh pegawai RRI Bengkulu setelah menyaksikan program acara dari Mario Teguh ini, khususnya pada episode ini, dari sekian banyak pegawai RRI Bengkulu yang menyaksikan acara ini rata-rata menyukai program acara Mario Teguh ini mereka mengaku merasakan perubahan sikap mereka seperti termotivasi, setelah menyaksikan acara ini, ada penyemangat tersendiri bagi mereka untuk memulai dan melakukan sesuatu dengan hati dan penuh percaya diri untuk menggapai sesuatu yang mereka harapkan.

Sedangkan reaksi yang ditimbulkan oleh para pegawai RRI Bengkulu dilihat dari komponen konatifnya, menunjukan bahwa reaksi dari para pegawai RRI Bengkulu cukup baik. Hal ini terbukti dari semua informan yang diwawancari mengenai reaksi mereka terkait acara dari Mario Teguh ini sangat baik, dan memberikan reaksi positif. Dahulunya mereka sering mengalami patah semagat baik itu dipengaruhi oleh lingkunagan pekerjaan di kantor, lingkungan, keluarga dan lainnya yang membuat semua pekerjaan mereka menjadi terganggu atau mendapatkan hasil yang kurang baik. Tetapi setelah menyaksikan tayangan pada episode ini, didapatkan ada perubahan sikap mereka untuk melakukan pekerjaan seperti yang disarankan oleh Mario Teguh dalam episode kali ini. Jadi, tayangan talkshowMario Teguh episode"Keberhasilan Demikian Dekat Dilidah, Tetapi Bisa Demikian Jauh Dari Jangkauan", dinilai mampu mempengaruhi sikap pegawai RRI Bengkulu yang dilihat dari 3 komponen sikap yaitu kognitif, afektif dan konatif dan hasilnya dapat membangkitkan motivasi kerja pada diri 
pegawai RRI Bengkulu.Seperti yang diungkapkan oleh saudari Elly yaitu:

"setelah saya memahami dari episode ini saya merasa masih banyak yang harus saya rubah, seperti berbicara, karena mengapa jika saya tidak merubah gaya bicara saya mungkin saya tidak akan bisa maju menjadi lebih baik lagi

dalam

pekerjaan".(Wawancara Jumat 8 April 2016)

Hal senada juga disampaikan oleh saudara Marli Efendi selaku penyiar RRI Bengkulu sebagai berikut:

"Ya, menurut saya hal tersebut harus ada dalam profesi saya selaku penyiar radio,karena mengapa jika saya salah dalam menyampaikan informasi maka saya tidak akan di percayai lagi selaku penyiar, begitu juga dengan intonasi suara,dan gaya berpakaian, ya kalo siaran di dalan studio, nah jika di luar sebagai mc bagaimana. Menurut saya ini sangat penting dalam profesi seseorang mau pun itu profesinya keberhasilan akan mendekati kita dengan sendirinya apabila kita sudah bekerja dengan sungguhsungguh.(Wawancara jumat 8 April 2016)

Hal ini menunjukan bahwa perubahan atau reaksi yang terjadi pada sejumlah pegawi RRI Bengkulu, yang benar-benar menyukai episode ini, mereka membenarkan dan menunjukkan perubahan atau reaksi dari mereka. Seperti perubahan dari gaya berpakaian mereka, gaya bicara, dan intonasi suara ketika siaran. Berbicara sopan bisa dilatih, mulailah berbicara hal-hal yang etis, positif dan bermanfaat. Kata-kata yang menyakitkan tidak mudah dilupakan pendengarnya, karena merasuk ke hati bukan ke telinga saja. Selain itu juga, kaku berbicara jangan keras-keras karena selain tidak sopan, kita juga terkesan tidak berkelas. Begitu kata Bapak Mario teguh sang motivator. Sikap pegawai RRI Bengkulu, dilihat dari komponen kognitif bahwa sikap mereka setelah menonton episode ini mereka terdorong untuk bekerja lebih giat lagi dalam mencapai kesuksesan dan keberhasilan dalam berkarir. Seperti ungkapan saudari Shovy bahwa:

"episode kali ini membuat saya menjadi terbuka, karena yang tadinya saya hanya bekerja seperti biasa saja, tetapi melalui pesan yang disampaikan pak mario teguh, saya tergugah untuk menjadi lebih baik lagi"..(Wawancara hari senin 11 April 2016)

Hal serupa juga di sampaikan oleh saudara Nurul yaitu:

"saya merasa ada semagat tersendiri setelah saya memahami isi pesan dari episodeini, di mana pekerjaan ini sangat bertentangan denga fisik saya, kan mayoritasnya wartawan itu adalah kaum pria, tetapi saya merasa bersemangat walaupun saya wanita saya bisa bekerja dan merasa nyaman dengan profesi saya".(Wawancara, Hari jumat 8 April 2016)

Hal ini menunjukan bahwa isi pesan pada episode ini sangat menarik dan bermanfaat khususnya bagi para pegawai RRI Bengkulu ini, bahkan bagi kehidupan kita sehari-hari pun hal ini sering terjadi tanpa kita sadari. Sebenarnya kesuksesan seseorang itu amat dengan mudah diraih jika saja kita bisa memulai sesuatu dengan perencanaan yang baik dan matang serta memiliki pikiran positif tentang apa yang kita kerjakan. Tentunya keberhasilan akan segera kita raih, atau bahkan sebalikanya, justru kesuksesan sudah dekat dengan kita namun kita tidak bisa memanfaatkannya atau menjalaninya dengan baik, yang ada kesuksesan itu akan menjauh dengan sendirinya. Intinya adalah bekerjalah dengan hati dan pikiran yang positif, jabatan dan kedudukan yang lebih baik akan segera kita raih dengan sendirinya 
dan jangan takut untuk gagal serta mencoba hal-hal yang baru.

\section{PEMBAHASAN}

Berdasarkan hasil penelitian, yang penulis peroleh bahwa rata-rata pegawai RRI Bengkulu menyukai dari tayangan acara MTGW ini dan acara Mario Teguh Golden Ways pada episode, Keberhasilan Demikian Dekat Dilidah, Tetapi Bisa Demikian Jauh Dari Jangkauan", yang disampaikan oleh Bapak Mario Teguh dinilai sangat baik, cocok dan bermanfaat untuk ditonton.

Menurut mereka tayangan pada episode ini sangat memberikan masukan dan motivasi untuk bekerja lebih giat lagi, untuk menggapai yang namanya kesuksesan. Karena kesuksesan tidak akan tercapai jika kita bekerja hanya sekedarnya saja. Memang di setiap pekerjaan penuh dengan tantangan, di bawah tekanan, dan persaingan. Terkadang hal ini membuat situasi hati merasa kurang nyaman dan bisa menurunkan semangat dalam pekerjaan. Melalui tayangan ini, pegawai RRI Bengkulu merasa termotivasi dalam melaksanakan pekerjaan mereka yang menuntut mereka agar lebih cepat, tangkas dan tepat dalam memberikan informasi dan pelayanan kepada masyarakat. Berdasarkan pengkajian berdasarkan teori S-O-R, dimana stimulus yang berupa pesan-pesan yang di sampaikan oleh Mario teguh pada acara talkshow pada episode ini dinilai sangat cocok dan baik untuk meningkatkan motivasi untuk menjadi lebih baik lagi, apa lagi dalam episode ini banyak memberikan pencerahan pikiran dan membangkitkan semangat tentang sebuah keberhasilan yang akan di gapai dalam pekerjaan. Dari segi organismnya atau si penerima pesan mengaku mereka menyukai dari sosok mario teguh ini selain memiliki kecerdasan tinggi ia di nilai mampu meberikan motivasi yang tepat dan mengena pada permasalahan yang tengah di bahas, seperti dalam episode ini dilihat dari arti judulnya sudah menggambarkan jika keberhasilan itu benar-benar mudah kita gapai apabila kita mengerjakan sesuatu itu dengan niat dan tekat yang bulat.

Sedangkan dari segi respon kelima informan yang di teliliti olah penulis menunjukan dan merasakan respon yang baik terhadap pesan yang ditayangkan olah Mario Teguh dalam episode ini. Tayangan mario teguh ini dianggap mampu memberikan perubahan sikap seperti sikap percaya diri yang tinggi, pola atau cara berpakaian dan berbicara yang baik. Terlebih pada episode ini karena kata-kata dan arti dari judul pada episode ini cukup memberikan motivasi tersendiri bagi yang menontonnya.

Dilihat dari segi stimulus pesan yang disampaikan oleh bapak Mario Teguh dalam tayangan episode ini cukup memberikan motivasi yang baik bagi pemirsanya, sedangkan dari segi organismnya dinilai mampu menarik perhatian dan mempengaruhi sikap bagi pemirsanya. Hal ini dapat dilihat dari adopsi kata-kata bapak Mario Teguh, cara berbicara hingga cara berpakaianpun ikut berubah. Sedangkan dari segi respon atau efek yang ditimbulkan atau yang mereka rasakan terhadap tayangan Mario Teguh ini, didapat adanya perubahan sikap yang dirasakan setelah menonton tayangan ini.

Selanjutnya adalah sikap pegawai RRI Bengkulu dilihat dari tiga komponen yakni komponen kognitif yang berupa persepsi mereka terhadap tayangan ini cukup baik terbukti bahwa tayangan talkshow Mario Teguh ini, persepsi pemirsanya terhadap tayangan episode ini sangat antusias dan baik. Dan dari komponen afektif yang menyangkut perasaan pemirsanya menunjukan bahwa kelima informan ini tertarik dan setuju dan dinilai bahwa tayangan talkshow dari Mario Teguh ini bisa memberikan motivasi dan mampu membangkitkan perasaan pemirsanya hingga tersentuh untuk melakukan perubahan dalam dirinya setelah mendapatkan saran dan keritikan dari bapak Mario teguh. 
Sedangkan dari komponen konatif menyebutkan perubahan sikap yang dirasakan oleh pegawai RRI Bengkulu terhadap tayangan talkshow Mario Teguh Golden Ways ini menunjukan adanya perubahan sikap pemirsanya seperti seperti perubahan gaya berbicara, berpakaian dan lainnya, terlebih sehingga pemirsanya tergerak hatinya untuk memulai yang baik lagi. Rata-rata pemirsanya menyukai dari tayangan talkshow Mario Teguh ini selain dinilai mampu memberikan informasi juga dianggap baik untuk dijadikan sebagai rujukan utama dalam mendapatkan katakata motivasi. Besar pengaruh yang di dapat dari menonton tayangan MTGW ini, tidak sedikit dari pemirsa mampu di pengaruhi oleh sang pembawa acara. Semua semua tidak terlepas dari acara dan teknik penyampaian pesan yang baik dari sang komunikator kepada komunikannya.

Tayangan episode ini di anggap mengena dan masuk akal sekali jika saja kita bekerja dengan sungguh-sungguh dan penuh rencana yang baik, maka keberhasilanpun akan segera dicapai, semua tergantung pada diri kita sendiri dan memulailah pekerjaan dengan hati yang ikhlas, jujur, dan penuh tanggung jawab.

\section{KESIMPULAN DAN SARAN Kesimpulan}

Berdasarkn hasil penelitian dan pembahasan yang telah penulis lakukan dapat ditarik kesimpulan sebagai berikut:

1. Tayangan talkshow Mario Teguh episode keberhasilan demikian dekat di lidah, tetapi bisa demikian jauh dari jangkauan, dinilai mampu memberikan informasi juga motivasi kerja yang baik bagi pegawai RRI Bengkulu.

2. Perubahan sikap dari komponen kognitif, persepsi pegawai RRI Bengkulu terhadap tayangan ini cukup baik terbukti bahwa tayangan talkshow Mario Teguh ini, mampe menarik minat terhadap tayangan episode ini.

3. Perubahan sikap dari komponen afektif, menunjukan bahwa pegawai RRI
Bengkulu sangat tertarik dan setuju bahwa tayangan talkshow Mario Teguh ini memberikan motivasi kerja.

4. Perubahan sikap dari komponen konatif, mampu mempengaruhi sikap pegawai RRI Bengkulu terhadap tayangan MTGW episode "Keberhasilan Demi Kian Dekat di Lidah, Tetapi Bisa Demikian Jauh Dari Jangkauan, seperti perubahan gaya berbicara, berpakaian dan lain-lain.

\section{Saran}

1. Diharapkan bisa memotivasi diri sendiri tanpa harus terus menonton tayangan talkshow MTGW, mengingat keterbatasan waktu dan tidak tayangnya lagi acara ini.

2. Penulis berharap ada penelitian berikutnya yang lebih mendalam dari penelitian ini, dengan menggabungkan dua pendekatan yang menggunakan metode kualitatif dan kuantitatif agar analisis yang di dapat lebih dalam lagi dan lebih bervariasi.

3. Bagi produksi media, disarankan lebih kreatif dan lebih banyak lagi dalam menampilkan acara tayangan talkshow yang lain, sehingga pemirsa tidak merasa jenuh dengan acara-acara yang ada di stasiun televisi.

\section{DAFTAR PUSTAKA}

Ardianto,2014.Sebuah Pengantar Komunikasi.PT Rajawali Grafindo Persada

Taylor,Bogdan,2002.Pengantar

Komunikasi Massa.Citar Wijaya Putra.

Cangara, 2005.Komunikasi Media Massa.Erlangga

Effendy,1990.Perkembangan Televisi.PT Rajawali Pers.Jakarta

Kuswandi, Wawan,1996.Jurnalistik Televisi.PT Persada Jaya.Jakarta

Karlinah,dkk,2010.Media Massa.Rajawali Persada.Jakarta

Koentjaraningrat, 2009. Metode Penelitian Masyarakat. PT. Gramedia. Jakarta 
Moleong,2013.Sebauh

Talkshow

Pengantar Acara

Televisi.Gramedia.Jakarta

Muntana, 1995. Pengantar Metode Penelitian.Graha Persada.Jakarta

Putri Helmalina (dalam skripsi Putri Helmalina "Analisis Fenomenologi Pada Program Mario Teguh Golden Ways di Metro TV") Universitas Islam Negeri Syarif Hidayatullah Jakarta.2011
Syahrul Mubaroq (dalam skripsi Syahrul Mubaroq "Analisis Program Mario Teguh Golden Ways di Metro $T V$ ”)Universitas Islam Negeri Syarif Hidayatullah Jakarta.2011 Sugiyono,2009.Memahami Penelitian Kualitatif.Alfabeta.Bandung

Wahyudi,1998.Pengantar Jurnalistik Televisi Sebuah Pengantar.PT Rosada Persada.Jakarta 